American Journal of Biochemistry and Biotechnology 5 (1): 40-46, 2009

ISSN 1553-3468

(C) 2009 Science Publications

\title{
Host Plant Mediated Population Variations of Cotton Whitefly Bemisia tabaci Gennadius (Aleyrodidae: Homoptera) Characterized with Random DNA Markers
}

\author{
${ }^{1}$ Yasodha Perumal, ${ }^{2}$ Murugan Marimuthu, \\ ${ }^{1}$ Abida Puthenpeedikal Salim and ${ }^{1}$ Balasubramanian Ponnusamy \\ ${ }^{1}$ Department of Plant Molecular Biology and Biotechnology, Centre for Plant Molecular Biology, \\ Tamil Nadu Agricultural University, Coimbatore-641003, Tamil Nadu, India \\ ${ }^{2}$ Department of Entomology, Kansas State University, 123 Waters Hall, Manhattan, KS, USA 66506
}

\begin{abstract}
Problem statement: Whitefly, Bemisia tabaci is an important sucking pest of field, horticultural and ornamental plants causing feeding injuries besides spreading disease by acting as a vector of Gemini viruses. The polyphagous nature of the pest makes it as a highly complex species. Approach: The influence of host plants utilized by the species on the population differences at molecular level was attempted using Random Amplified Polymorphic DNA (RAPD) markers. Results: Ten RAPD primers out of the total seventeen primers screened produced 236 markers. The total number of bands obtained from each primer ranged from 11-35 with an average of 23.60 bands per primer. Of the pair wise combination among thirteen species, Srivilliputhur population showed the highest similarity index $(0.826)$ while the lowest $(0.111)$ was recorded by Namakkal population. The similarity coefficient based on the 236 RAPD markers generated ranged from 0.111-0.826. Three major clusters were formed from UPGMA dendrogram, which was constructed based on Jaccard's similarity. PCR screening demarcated the whitefly population based on the host species. The first cluster included population collected from okra and cotton, while second cluster comprised of population from eggplant and cauliflower and the third cluster included population from eggplant. It could be deduced that population from cotton and okra had 50\% similarity, while 60-70\% similarity was observed for population from eggplant and cauliflower. Conclusion: Our investigation offered the lead that within a narrow geographical region there exits variation based on host plants being utilized by the whitefly population.
\end{abstract}

Key words: Bemisia tabaci, host plants, RAPD primers, PCR, UPGMA

\section{INTRODUCTION}

Bemisia tabaci Gennadius is a plant sap-sucking insect in the family, Aleyrodidae, superfamily Aleyrodoidea and order, Hemiptera. It is broadly polyphagous, feeding on an estimated 900 hosts $^{[1]}$. Since from 1990's, it has caused escalating problems to economically important field, horticultural crops and ornamental plants ${ }^{[2]}$. Three types of damage may be caused by whitefly; they include direct damage, indirect damage and virus transmission. Directly, it pierces and sucks the sap from foliage of plants causing feeding damage. This feeding weakens and creates early wilting of the plant and reduces the plant growth rate and yield. It may also cause leaf chlorosis, leaf withering, premature dropping of leaves and death of the plants. Infestations of whitefly nymphs are associated with the occurrence of irregular ripening of tomatoes ${ }^{[3]}$.
Taxonomy of the whitefly has long been known to be problematic because of morphological traits of adults do not readily permit differentiation between genera or species.

Recently, B. tabaci has developed several biotypes and acts as a virulent vector of plant viruses in agricultural ecosystems owing to a combination of insecticide resistance, reduction in natural enemies and increased monoculture production of crops in subtropical and tropical areas. The recent proliferation reported is unlikely to be the consequence of a modification in cultural practices, which encourages this whitefly, as the phenomenon occurred at the same time over the entire world ${ }^{[4]}$. To date 41 distinct populations of $B$. tabaci have been characterized using a variety of techniques and 24 of these populations given a specific biotype designation ${ }^{[5]}$. Molecular and allozyme data from these studies supports the idea that

Corresponding Author: Murugan Marimuthu, Department of Entomology, Kansas State University, 123 Waters Hall, Manhattan, KS, USA 66506-4004 Tel: +785-532-6082 Fax: 785-317-9680 
B. tabaci is a suite of highly cryptic sibling species that cannot currently be distinguished morphologically. Perring ${ }^{[5]}$ reviewed the species complex and proposed the existence of seven distinct groups based on comparison of populations from various locations.

New areas have been occupied by the virulent biotypes as noticed with the simultaneous outbreak of new symptoms unknown with $B$. tabaci such as squash silver leaf, tomato irregular ripening and yellowing and specific biological behaviors viz., severe attacks on nonsusceptible crops such as cabbage and resistance to most of the insecticides ${ }^{[6]}$. Moreover, newer viruses transmitted by whiteflies were also reported and is continuing even today ${ }^{[6]}$. As early as $1986^{[2,7,8]}$, revealed the existence of a new biotype of B. tabaci named 'B' biotype.

It was raised to the rank of a new species ${ }^{[9]}$ and was named Bemisia argentifolii Bellows and Perring, which produces unique symptoms of "squash silver leaf". Recent research has tended to prove that B. tabaci corresponds to a species or biotypes complex in phylogenetic evolution. Its distinctive characteristics still have to be revealed by using methods different from the methods commonly used in taxonomy ${ }^{[10,11]}$. Up to now, approximately 24 biotypes have been identified and characterized to different degrees. It was primarily divided in to $\mathrm{B}$ biotype, $\mathrm{Q}$ biotype and non $\mathrm{B} / \mathrm{Q}$ biotype. The non $\mathrm{B} / \mathrm{Q}$ biotypes includes more than 20 biotypes such as A, K, D, E, G, H, L, M, ${ }^{[12]}$.

The taxonomy of the whitefly is based on the morphological characteristics of the fourth nymphal stage (pupal case) ${ }^{[13]}$. However, biotypes of the B. tabaci complex are morphologically indistinguishable. Recently, molecular markers have been used to distinguish populations of B. tabaci. These populations or biotypes can be recognized by esterase markers, Random Amplified-length Polymorphism DNA (RAPD), Amplified Fragment-Length Polymorphism (AFLP), mitochondrial, ribosomal and microsatellite markers ${ }^{[14-20]}$.
In addition, many specific genes are being utilized to understand the genetic diversity of the $B$. tabaci species complex ${ }^{[21]}$. Although much of the information is available on the biotype prevalence based on the locations and regions, molecular information on the genetic diversity of populations based on host plants is scarce. This paper attempts to address our hypothesis that the population of the whitefly varies widely depending upon the host plants being utilized by the whitefly and are distinct within a narrow region or locality with polycrop systems.

\section{MATERIALS AND METHODS}

Insect population samples: Whitefly pre-pupal instar stages were collected from the middle leaves of the different host plants along with the host plant parts and allowed for adult emergence using insect emergence cages at the laboratory. The emerging adult female whiteflies were separated and preserved immediately in vials containing $\mathrm{C}-\mathrm{TAB}$ buffer. The samples were maintained at $-20^{\circ} \mathrm{C}$ until DNA extraction (maximum period of 15 days). A total of 13 whitefly samples were collected from 13 different localities of Tamil Nadu, India depicting a garden-land ecosystem with field and horticultural crops that are being grown round the year (Table 1).

DNA extraction: Total nucleic acids were extracted from individual female whiteflies using $\mathrm{CTAB}$ (hexadecyl trimethyl ammonium bromide) method ${ }^{[22]}$ with necessary modifications. Quality and quantity of the isolated DNA was measured in Nanodrop ${ }^{\circledR}$ ND1000 spectrophotometer (nanodrop technologies, USA) and $0.8 \%$ Agarose gel electrophoresis before being used as the template DNA for all Polymerase Chain Reactions (PCR). The reagents were purchased from Bangalore Genei Ltd., Bangalore, India.

Table 1: Sampling locations of Tamil Nadu for assessing diversity in B. tabaci populations from different host plants

\begin{tabular}{|c|c|c|c|c|c|c|}
\hline Plant source & $\begin{array}{l}\text { Plant variety/ } \\
\text { hybrid }\end{array}$ & $\begin{array}{l}\text { Date of } \\
\text { sampling }\end{array}$ & Location & Ecosystem & Coordinate & $\begin{array}{l}\text { Population } \\
\text { code }\end{array}$ \\
\hline \multirow{6}{*}{$\begin{array}{l}\text { Eggplant: Solanum melongena L. } \\
\text { (Solanaceae) }\end{array}$} & $\mathrm{CO}_{2}$ & $15 / 09 / 2007$ & Thiruchirappalli & Polycrop plain terrains & $10^{\circ} 50^{\prime} \mathrm{N}-78^{\circ} 46^{\prime} \mathrm{E}$ & EPTPA \\
\hline & Annamalai & $16 / 09 / 2007$ & Pudukkottai & Polycrop plain terrains & $10^{\circ} 23^{\prime} \mathrm{N}-78^{\circ} 52^{\prime} \mathrm{E}$ & EPPKT \\
\hline & MDU1 & $19 / 09 / 2007$ & Madurai, & Polycrop plain terrains & $09^{\circ} 58^{\prime} \mathrm{N}-78^{\circ} 10^{\prime} \mathrm{E}$ & EPMDU \\
\hline & $\mathrm{CO}_{2}$ & $24 / 09 / 2007$ & Coimbatore, & Polycrop plain terrains & $11^{\circ} 00^{\prime} \mathrm{N}-77^{\circ} 00^{\prime} \mathrm{E}$ & EPCBE \\
\hline & Mohini^$^{\wedge}$ & 06/10/2007 & Dharmapuri & Polycrop plain terrains & $12^{\circ} 08^{\prime} \mathrm{N}-78^{\circ} 13^{\prime} \mathrm{E}$ & EPDPI \\
\hline & $\mathrm{CO}_{2}$ & $15 / 10 / 2007$ & Erode & Polycrop plain terrains & $11^{\circ} 20^{\prime} \mathrm{N}-77^{\circ} 46^{\prime} \mathrm{E}$ & EPEDE \\
\hline Okra: Abelmoschus esculentus (L.) & Mahyco $10^{\wedge}$ & $25 / 10 / 2007$ & Dindigul & Polycrop plain terrains & $10^{\circ} 22^{\prime} \mathrm{N}-78^{\circ} 00^{\prime} \mathrm{E}$ & OKDGL \\
\hline \multirow[t]{3}{*}{ Moench. (Malvaceae) } & US Agriseeds $109^{\wedge}$ & 06/10/2007 & Krishnagiri & Polycrop plain terrains & $12^{\circ} 32^{\prime} \mathrm{N}-78^{\circ} 16^{\prime} \mathrm{E}$ & OKKGI \\
\hline & US Agriseeds $7109^{\wedge}$ & $02 / 11 / 2007$ & Attur & Polycrop plain terrains & $11^{\circ} 36^{\prime} \mathrm{N}-78^{\circ} 39^{\prime} \mathrm{E}$ & OKATR \\
\hline & Champion^ & $15 / 11 / 2007$ & Namakkal & Polycrop plain terrains & $11^{\circ} 13^{\prime} \mathrm{N}-78^{\circ} 13^{\prime} \mathrm{E}$ & OKNKL \\
\hline Cotton: Gossypium hirsutum L. & MCU 5 & $25 / 11 / 2007$ & Srivilliputhur & Polycrop plain terrains & $10^{\circ} 12^{\prime} \mathrm{N}-77^{\circ} 30^{\prime} \mathrm{E}$ & COSVR \\
\hline (Malvaceae) & LRA 5166 & $27 / 11 / 2007$ & Thirunelveli & Polycrop plain terrains & $08^{\circ} 44^{\prime} \mathrm{N}-77^{\circ} 44^{\prime} \mathrm{E}$ & COTVI \\
\hline $\begin{array}{l}\text { Cauliflower: Brassica oleracea } \mathrm{L} \text {. } \\
\text { (Botrytis) (Brassicaceae) }\end{array}$ & Snow ball-16 & $16 / 09 / 2007$ & Ooty & Polycrop hill terrains & $11^{\circ} 24^{\prime} \mathrm{N}-76^{\circ} 42^{\prime} \mathrm{E}$ & CFOTY \\
\hline
\end{tabular}


RAPD assays: RAPD analyses were carried out according to Lima et al. ${ }^{[18]}$ with some modifications. Amplification reactions were performed in a $20 \mu \mathrm{L}$ reaction mix, containing a final concentration of $10 \mathrm{mM}$ dNTPs, $25 \mathrm{mM} \mathrm{MgCl}_{2}$, dimethyl sulfoxide, Taq

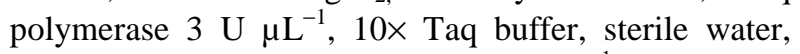
primer $100 \mathrm{nmol}$ and DNA $20-25 \mathrm{ng} \mathrm{uL}^{-1}$. The RAPD analysis was performed with seventeen decamers supplied by Operon Technologies Inc., California, USA. Amplification was performed in Thermocycler ${ }^{\circledR}$ (BioRad, USA) programmed as one cycle of initial denaturation $95^{\circ} \mathrm{C}$ for $2 \mathrm{~min}$; one cycle of denaturation at $95^{\circ} \mathrm{C}$ for $1 \mathrm{~min}$; 30 cycles each of $95^{\circ} \mathrm{C}$ for $1 \mathrm{~min}$, annealing at $40^{\circ} \mathrm{C}$ for $1 \mathrm{~min}$, extension at $72^{\circ} \mathrm{C}$ for $1 \mathrm{~min}$ and final extension at $72^{\circ} \mathrm{C}$ for $7 \mathrm{~min}$. The PCR products were separated in $1.5 \%$ agarose gel electrophoresis.

Analysis of PCR amplification profiles: Data obtained by scoring the RAPD profiles of the ten primers individually were subjected for cluster analyses. PCR amplification products of the thirteen samples were scored as presence (1) or absence (0) of bands. The data matrix was used to calculate Jaccard's similarity coefficient ${ }^{[23]}$, which does not consider the joint absence of a marker as an indication of similarity. The similarity values were used for cluster analyses. Sequencial Agglomerative Hierarchial Non-overlapping (SAHN) clustering was done using Unweighted PairGroup Method with Arithmetic averages (UPGMA). This analysis was performed using NTSYS-pc software, version $2.0^{[24]}$.

\section{RESULTS}

Ten out of the seventeen primers screened produced clear bands on the RAPD amplifications and were subjected for analysis. These ten primers (Table 2) got amplified to a total of 236 markers. The total number of clear bands obtained from each primer ranged from 11 (OPP 15) to 35 (OPA 13) with an average of 23.60 bands per primer. The size of the amplicons ranged from $100 \mathrm{bp}$ to more than $1000 \mathrm{bp}$, while clearly resolved bands were obtained below $500 \mathrm{bp}$ only in the case of OPE 04 primer. RAPD amplification pattern is shown in Fig. 1-3 for illustration. RAPD patterns produced by the primers varied in primer screening step and also in final analyses. Genetic relationships between populations are shown in Table 3.

The similarity coefficient based on 236 RAPD markers ranged from $0.111-0.826$. Of the pair wise combination among thirteen samples of whitefly,
Table 2: Total number of markers and percent of polymorphism developed among $B$. tabaci population from different host plants by the RAPD primers

\begin{tabular}{lllll}
\hline $\begin{array}{l}\text { Primer } \\
\text { name }\end{array}$ & $\begin{array}{l}\text { No. of markers } \\
\text { generated }\end{array}$ & $\begin{array}{l}\text { Polymorphic } \\
\text { markers }\end{array}$ & $\begin{array}{l}\text { Monomorphic } \\
\text { markers }\end{array}$ & $\begin{array}{l}\text { Percentage of } \\
\text { polymorphism }\end{array}$ \\
\hline OPA 01 & 35 & 35 & - & 100.00 \\
OPA 07 & 26 & 26 & - & 100.00 \\
OPA 08 & 33 & 33 & - & 100.00 \\
OPA 13 & 17 & 17 & - & 100.00 \\
OPC 02 & 33 & 33 & - & 100.00 \\
OPC 08 & 29 & 29 & - & 100.00 \\
OPC 15 & 24 & 24 & - & 100.00 \\
OPE 04 & 13 & 11 & 2 & 84.62 \\
OPE 08 & 15 & 15 & - & 100.00 \\
OPE 15 & 11 & 11 & - & 100.00 \\
\hline
\end{tabular}

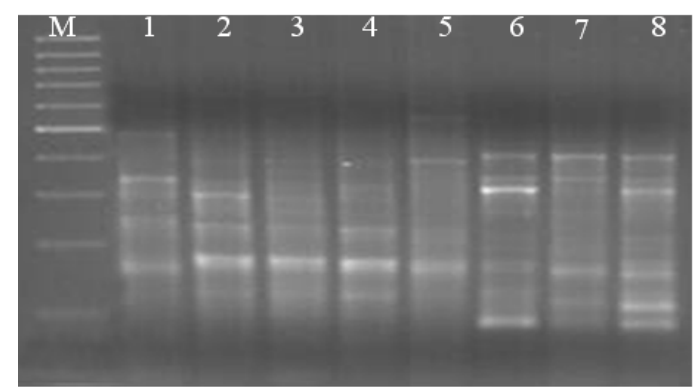

Fig. 1: A representative RAPD reaction set for the differentiation of whitefly population. M: 100bp DNA ladder (Bangalore Genei, Bangalore, India); samples (1-8) on the right of the marker were amplified using primer OPE 04. (Lane 15): Individual whiteflies from eggplant: Coimbatore (EPCBE), Thiruchirappalli (EPTPA), Madurai (EPMDU), Dharmapuri (EPDPI), Pudukkottai (EPPKT). (Lane 6-7): Individual whiteflies from Okra: Namakkal (OKNKL), Krishnagiri (OKKGI), (Lane 8): Individual whitefly from Cauliflower: Ooty (CFOTY)

Srivilliputhur population showed the highest similarity index (0.826), while the lowest (0.111) was recorded by Namakkal population. An UPGMA dendrogram based on Jaccard's similarity coefficient was constructed for the thirteen samples of whitefly. Three major clusters viz., A, B and C are evident from the dendrogram (Fig. 4). PCR screening demarcates the whitefly population based on the host plant species. The major cluster $\mathrm{A}$ is again divided into minor groups viz., $A_{1}$ and $A_{2}$. The minor cluster $A_{1}$ is comprised of population from cotton host plants from Srivilliputhur and Thirunelveli areas, while $\mathrm{A}_{2}$ comprised of okra plant collected whiteflies from areas viz., Dindigul, Krishnagiri, Attur and Namakkal. The major cluster $\mathrm{B}$ is further divided into $\mathrm{B}_{1}, \mathrm{~B}_{2}$ and $\mathrm{B}_{3}$. 
Am. J. Biochem. \& Biotech., 5 (1): 40-46, 2009

Table 3: Dendrogram based on Jaccard's similarity coefficient showing relationship among B. tabaci populations from different host plants and regions of Tamil Nadu, India using RAPD markers

\begin{tabular}{|c|c|c|c|c|c|c|c|c|c|c|c|c|c|}
\hline Case & CFOTY & EPTPA & EPPKT & EPMDU & EPEDE & EPDPI & EPCBE & OKNKL & OKATR & OKKG & OKDGL & COTVI & COSVR \\
\hline$\overline{\mathrm{CFOTY}}$ & 1.000 & & & & & & & & & & & & \\
\hline EPTPA & 0.400 & 1.000 & & & & & & & & & & & \\
\hline EPPKT & 0.181 & 0.041 & 1.000 & & & & & & & & & & \\
\hline EPMDU & 0.269 & 0.333 & 0.150 & 1.000 & & & & & & & & & \\
\hline EPEDE & 0.541 & 0.285 & 0.285 & 0.360 & 1.000 & & & & & & & & \\
\hline EPDPI & 0.480 & 0333 & 0.173 & 0.545 & 0.727 & 1.000 & & & & & & & \\
\hline EPCBE & 0.333 & 0.206 & 0.300 & 0.269 & 0.681 & 0.608 & 1.000 & & & & & & \\
\hline OKNKL & 0.250 & 0.344 & 0.111 & 0.233 & 0.413 & 0.464 & 0.600 & 1.000 & & & & & \\
\hline OKATR & 0.343 & 0.312 & 0.178 & 0.250 & 0.466 & 0.419 & 0.653 & 0.807 & 1.000 & & & & \\
\hline OKKGI & 0.178 & 0.230 & 0.150 & 0.071 & 0.307 & 0.214 & 0.375 & 0.541 & 0.538 & 1.000 & & & \\
\hline OKDGL & 0.206 & 0.259 & 0.190 & 0.103 & 0.384 & 0.285 & 0.458 & 0.560 & 0.615 & 0.777 & 1.000 & & \\
\hline COTVI & 0.156 & 0.241 & 0.125 & 0.096 & 0.310 & 0.225 & 0.370 & 0.366 & 0.375 & 0.545 & 0.500 & 1.000 & \\
\hline COSVR & 0.242 & 0.212 & 0.240 & 0.117 & 0.400 & 0.272 & 0.464 & 0.323 & 0.411 & 0.461 & 0.538 & 0.826 & 1.000 \\
\hline
\end{tabular}

Cauliflower: Ooty (CFOTY); Eggplant: Thiruchirappalli (EPTPA); Pudukkottai (EPPKT); Madurai (EPMDU); Erode (EPEDE); Dharmapuri (EPDPI); Coimbatore (EPCBE); Okra: Namakkal (OKNKL); Attur (OKATR); Krishnagiri (OKKGI); Dindigul (OKDGL); Cotton: Thirunelveli (COTVI); Srivilliputhur (COSVR)

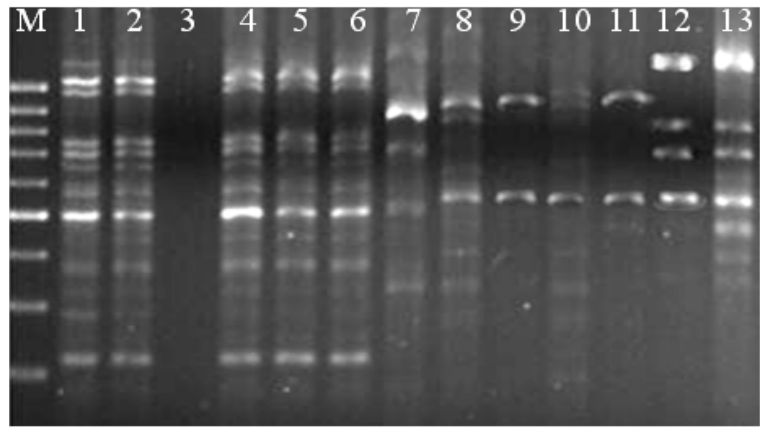

Fig. 2: A representative RAPD reaction set for the differentiation of whitefly population. M: 100bp DNA ladder (Bangalore Genei, Bangalore, India); samples (1-13) on the right of the marker were amplified using primer OPA 12: (Lane 1-6): Individual whiteflies from eggplant: Coimbatore (EPCBE), Pudukkottai (EPPKT), Thiruchirappalli (EPTPA), Madurai (EPMDU), Dharmapuri (EPDPI), Erode (EPEDE). (Lane 7): Individual whiteflies from cauliflower: Ooty (CFOTY). (Lane 8-11): Individual whiteflies from okra: Dindigul (OKDGL), Namakkal (OKNKL), Krishnagiri (OKKGI), Attur (OKATR). (Lane 12 and 13): Individual whiteflies from cotton: Thirunelveli (COTVI), Srivilliputhur (COSVR)

The minor clusters $B_{1}$ and $B_{2}$ represented the population of whiteflies collected from eggplant at Thiruchirappalli, Madurai respectively and $\mathrm{B}_{3}$ included population from eggplant collected at Coimbatore, Dharmapuri, Erode and cauliflower at Ooty. The cluster $\mathrm{C}$ distinctly represented the population from eggplant host alone collected from Pudukkottai.

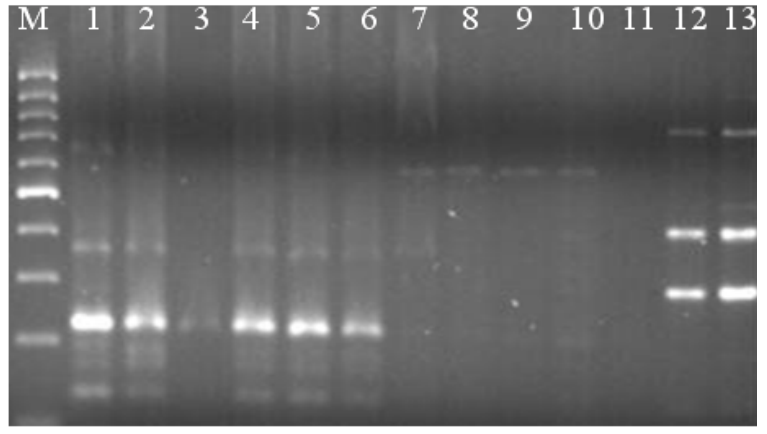

Fig. 3: A representative RAPD reaction set for the differentiation of whitefly population. M: 100bp DNA ladder (Bangalore Genei, Bangalore, India); samples (1-13) on the right of the marker were amplified using primer OPA 17: (Lane 1-6): Individual whiteflies from eggplant: Coimbatore (EPCBE), Pudukkottai (EPPKT), Thiruchirappalli (EPTPA), Madurai (EPMDU), Dharmapuri (EPDPI), Erode (EPEDE). (Lane 7): Individual whiteflies from cauliflower: Ooty (CFOTY). (Lane 8-11): Individual whiteflies from okra: Dindigul (OKDGL), Namakkal (OKNKL), Krishnagiri (OKKGI), Attur (OKATR). (Lane 12 and 13): Individual whiteflies from cotton: Thirunelveli (COTVI), Srivilliputhur (COSVR)

The dendrogram deduced that whitefly population from cotton and okra had 50 similarity, while 60-70\% similarity was observed for population from eggplant and cauliflower. 
Am. J. Biochem. \& Biotech., 5 (1): 40-46, 2009

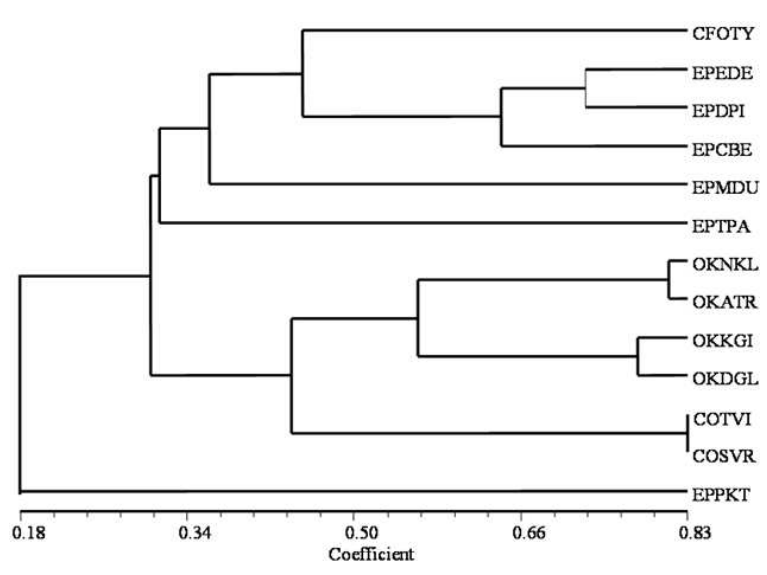

Fig. 4: Dendrogram showing the UPGMA clustering of B. tabaci originating from different localities and host plants based on RAPD-PCR polymorphisms using 236 markers

\section{DISCUSSION}

Whiteflies collected from four different hosts viz., brinjal, cotton, okra and cauliflower in various locations of Tamil Nadu, mostly with garden-land conditions under tropical climatic conditions except Ooty with a subtropical topography were evaluated for genetic diversity using RAPD markers. In India, during the last decade, molecular markers have become available for identifying variants of $B$. tabaci that are otherwise indistinguishable morphologically. RAPD-PCR has been used to differentiate $B$. tabaci variants ${ }^{[18,25,26]}$ and to estimate the genetic relationships of closely related populations from the same geographical locations $^{[19,27,28]}$. More recently, conserved genome sequences have been used to elucidate population genetics and have provided a broad biogeographical framework for B. tabaci $i^{[16,17,27-29]}$. More number of markers was produced by OPA 13 and was previously reported with Lima et al. ${ }^{[18]}$ and amplified the whitefly sequence producing 20 markers. In the present investigation, diversity of the whitefly population is seen based on the host species. It is well evident from the dendrogram, which resulted with three major clusters accommodating whitefly populations from different host plants. The major cluster $\mathrm{A}$ is again divided into minor clusters $\mathrm{A}_{1}$ and $\mathrm{A}_{2}$ representing cotton and okra host populations. Lima et al. ${ }^{[18]}$ reported that biotype $\mathrm{B}$ individuals were scattered independently in the localities where the samples were collected especially from cotton. The major cluster B at majority represented the whitefly population collected from eggplant and is further divided into $B_{1}, B_{2}$ and $B_{3}$ representing the regions. The cluster $\mathrm{C}$ acted differently comprising whiteflies collected from eggplant of Pudukkottai area. Since population from eggplant at Pudukkottai alone being formed into a separate cluster, it may be suspected to be reproductively isolated from population obtained from other crops or within eggplant itself. Similarly, some clusters joining individuals according to the host plants were evident ${ }^{[18]}$. Their results suggested that a differentiation of populations has already occurred, mainly according to the host plant, instead of the geographical region where populations are localized and they had reported that there was no grouping of samples collected on different crops in the same state. Among the biotypes of B. tabaci, the B biotypes, in the previous two decades has been distributed widely and caused tremendous losses world wide as a pest and vector of virus diseases $^{[2,10,30,31]}$. The $\mathrm{B}$ biotype has distinctive biological traits, together with esterase and RAPD patterns that showed little variation ${ }^{[2,7,26]}$.

Three distinct bands of sizes viz., 350, $800 \mathrm{bp}$ and $1 \mathrm{~kb}$ were produced by B11 primer $^{[32]}$, similar to that in our study clearly distinct bands of $500 \mathrm{bp}$ and $1 \mathrm{~kb}$ were produced by the primer OPA 12, while resolved bands were obtained below 500 bp using OPE 04 primer. The $\mathrm{B}$ biotype was first recorded in the Kolar district of Karnataka state, South India, during the summer growing season (March-June) of $1999^{[30]}$. In a different study ${ }^{[32]}$, cluster analyses of RAPD data separated the B. tabaci samples into north and south Karnataka groups. It had being inferred that different cropping pattern and diverse climatic conditions in the northern and southern regions of Karnataka may be responsible for that apparent diversity in B. tabaci, which otherwise grouped on geographic location. However, divisions were not based on the host-plant from which the samples were collected, which was one of the criteria used to identify two B. tabaci biotypes (cassava and sweet potato) in South India ${ }^{[33]}$. Importantly our investigation offers the lead that within a narrow geographical region there exits variation based on host plants being utilized by the whitefly population.

Two thoughts are expected to arise from our present study. One may be that both $\mathrm{A}$ and $\mathrm{B}$ clusters are distinct biotypes, while $\mathrm{C}$ cluster may come under either A/B. On the second set, the clusters A and B may represent a single biotype whereas the cluster $\mathrm{C}$ may be a separate biotype. Biotype ' $\mathrm{B}$ ' is now being present in most of South India from the original point of introduction during 1999 at Kolar district Karnataka ${ }^{[32]}$, bordering Dharmapuri district, Tamil Nadu. The rapid spread of whitefly ' $\mathrm{B}$ ' biotype is being experienced in South India as has been observed in other parts of the 
world $^{[8,17,29]}$. The whitefly population from cotton is denotified as "B biotype" [18]. Therefore in the present study, it is assumed that the population obtained from cotton may be confirmed as ' $\mathrm{B}$ ' biotype.

The whitefly population harboring cabbage has been adjudged as ' $\mathrm{B}$ ' biotype ${ }^{[32]}$, hence, it may be true that whitefly samples collected from cauliflower, a member of Brassicaceae family accommodating also cabbage, may be a 'B' biotype. Overall, our study confirms that there exists population isolations based on host plants among the whitefly, B. tabaci population and needs further molecular analyses to understand the physiological and evolutionary relationships, which may through lights for taxonomical perspectives and pest management decisions.

\section{CONCLUSION}

Genetic variability assessment in cotton whitefly B. tabaci populations originating from different host plants and from different locations of Tamil Nadu, India indicates that the population is diversified based on the host species. Clustering pattern observed in the dendrogram showed that at least two distinct biotypes exist among the populations collected within the narrow region of a state. These differences may be influencing the virus vectoring capabilities of the whitefly population and also their susceptibility to insecticides, which needs further studies.

\section{ACKNOWLEDGEMENT}

The USAID supported "IPM CRSP Regional IPM Research and Education for South Asia" scheme, Virginia Tech, USA is acknowledged for the financial support. The Department of Plant Molecular Biology and Biotechnology, Centre for Plant Molecular Biology, Tamil Nadu Agricultural University, Coimbatore, India is acknowledged for providing the facilities to carryout the research.

\section{REFERENCES}

1. Perring, T.M., A.D. Cooper, R.J. Rodriguez, C.A. Farrar and T.S. Bellows, 1993. Identification of a whitefly species by genomic and behavioral studies. Science, 259: 74-77. DOI: 10.1126/science.8418497

2. Costa, H.S. and J.K. Brown, 1991. Variation in biological characteristics and esterase patterns among populations of Bemisia tabaci and the association of one population with silverleaf symptom induction. Entomol. Exp. Appli., 61: 211-219. DOI: $10.1007 / \mathrm{BF} 00187724$
3. Kato, K., M. Onuki, S. Fuji and K. Hanada, 1998. The first occurrence of tomato yellow leaf curl virus in tomato (Lycopersicon esculentum Mill.) in Japan. Ann. Phytopathol. Soc. Jap., 64: 552-559.

4. Commonwealth Agricultural Bureau, 1986. Bemisia tabaci (Gennadius). Distribution Maps of Pests. Map no.284. Ascot: CAB International.

5. Perring, T.M., 2001. The Bemisia tabaci species complex. Crop Protect., 20: 725-737. DOI: 10.1016/S0261-2194(01)00109-0

6. Ryckewaert, P. and C. Alauzet, 2001. Characterization by electrophoresis of bemisia from the lesser antilles. J. Applied Entomol., 125: 263-266. DOI: 10.1046/j.1439-0418.2001.00536.x

7. Costa, H.S., D.E. Ullman, M.W. Johnson and B.E. Tabanishk, 1993. Association between B. tabaci and reduced growth, yellowing and stem blanching of lettuce and Kai Choy. Plant Dis., 77: 969-972. DOI: 10.1094/PD-77-0969

8. Schuster, D.J., T.F. Mueller, J.B. Kring and J.F. Price, 1990. Relationship of sweetpotato whitefly to new tomato fruit disorder in Florida. Hortscience, 25: $1618-1620$.

http://cat.inist.fr/?aModele=afficheN\&cpsidt $=5428447$

9. Bellows, T.S., T.M. Perring, R.J. Gill and D.H. Headrick, 1994. Description of a species of Bemisia (Homoptera: Aleyrodidae). Ann. Entomol. Soc. Am., 87: 195-206.

http://www.fao.org/agris/search/display.do?f=./199 5/v2106/US9450152.xml;US9450152

10. Brown, J.K., D.R. Frohlich and R.C. Rosell, 1995. The sweetpotato or silver leaf whiteflies: Biotypes of bemisia tabaci or a species complex?. Ann. Rev. Entomol., 40: 511-534.

DOI: 10.1146/annurev.en.40.010195.002455

11. Perring, T.M., 1996. Biological Differences of two Species of Bemisia that Contribute to Adaptive Advantage. In: Bemisia 1995 Taxonomy, Biology, Damage, Control and Management, Gerling, D. and R.T. Mayer (Eds.). Intercept Ltd. andover, Hants, UK., ISBN: 1898298335, pp: 3-16.

12. Burban, C., L.D.C. Fishpool, C. Fauquet, D. Fargette and J.C. Thouvenel, 1992. Host associated biotypes within West African populations of the whitefly Bemisia tabaci (Genn.), (Hom., Aleyrodidae). J. Applied Entomol., 113: 416-423. http://www.csa.com/ids70/linkabst.php?issn=0931$2048 \&$ vol $=113 \&$ firstpage $=416$

13. Viscarret, M.M., I. Torres-Jerez, E. Agostini de Manero and S.N. Lopez et al., 2003. Mitochondrial DNA evidence for a distinct New World group of Bemisia tabaci (Gennadius) (Hemiptera: Aleyrodidae) indigenous to argentina and bolivia and presence of the old world b biotype in argentina. Ann. Entomol. Soc. Am., 96: 65-72. DOI: 10.1603/00138746(2003)096[0065:MDEFAD]2.0.CO;2 
14. Byrne, F.J. and A.L. Devonshire, 1991. In vivo inhibition of esterase and acetylcholine esterase activities by profenofos treatments in the tobacco whitefly Bemisia tabaci (Genn): Implications for routine biochemical monitoring of these enzymes. Pestic. Biochem. Physiol., 40: 198-204. http://www.sciencedirect.com/science?_ob=Publication URL\&_cdi=6984\&_pubType=J\&_acct=C000025157\&_ version $=1 \&$ _urlVersion $=0 \&$ _userid $=508790 \& \mathrm{md} 5=9 \mathrm{a} 9 \mathrm{~b}$ daca9cb28e14628c4d7b954e8040\&jchunk=40\#40

15. Cervera, M.T., J.A. Cabezas, B. Simon, J.M. Martinez Zapater, F. Beitia and J.L. Cenis, 2000. Genetic relationships among biotypes of Bemisia tabaci (Hemiptera: Aleyrodidae) based on AFLP analysis. Bull. Entomol. Res., 90: 391-396. DOI: 10.1017/S0007485300000523

16. De Barro. P.J., F. Driver, J.W.H. Trueman and J. Curran, 2000. Phylogenetic relationship of world populations of Bemisia tabaci (Gennadius) using ribosomal ITS1. Mol. Phylogen. Evolut., 16: 29-36. DOI: $10.1006 / \mathrm{mpev} .1999 .0768$

17. Frohlich, D.R., I. Torres-Jerez, I.D. Bedford, P.G. Markham and J.K. Brown, 1999. A phylogeographical analysis of Bemisia tabaci species complex based on mitochondrial DNA markers. Mol. Ecol., 8: 1683-1691. DOI: 10.1046/j.1365-294x.1999.00754.x

18. Lima, L.H.C., D. Navia, P.W. Inglis and M.R.V. De Oliveira, 2000. Survey of Bemisia tabaci (Gennadius) (Hemiptera: Aleyrodidae) biotypes in Brazil using RAPD markers. Genet. Mol. Biol., 23: 781-785. DOI: 10.1590/S141547572000000400012

19. Moya, A., P. Guirao, D. Cifuentis, F. Beitia and J.L. Cenis, 2001. Genetic diversity of Iberian populations of Bemisia tabaci (Hemiptera: Aleyrodidae) based on random amplified polymorphic DNA-polymerase chain reaction. Mol. Ecol., 10: 891-897. DOI: 10.1046/j.1365294X.2001.01221.x

20. Tsagkarakou, A. and N. Roditakis, 2003. Isolation and characterization of microsatellite loci in B. tabaci (Hemiptera: Aleyrodidae), Mol. Ecol. Notes, 3: 196-198. DOI: 10.1046/j.1471-8286.2003.00393.x

21. Hsieh, C.H., C.H. Wang and C.C. Ko, 2006. Analysis of Bemisia tabaci (Hemiptera: Aleyrodidae) species complex and distribution in Eastern Asia based on mitochondrial DNA markers. Ann. Entomol. Soc. Am., 99: 768-775. DOI: 10.1603/0013-8746(2006)99[768:AOBTHA]2.0.CO;2

22. Doyle, J.J. and J.L. Doyle, 1987. A rapid DNA isolation procedure from small quantities of fresh leaf tissue. Phytochem. Bull., 19: 11-15. http://irc.igd.cornell.edu/Protocols/DoyleProtocol.pdf
23. Sneath, P.H.A. and R.R. Sokal, 1973. Numerical Taxonomy. The Principles and Practice of Numerical Classification. Freeman, San Francisco, ISBN: 0716706970, pp: 573.

24. Rohlf. F.J., 1998. NTSYS-pc (Numerical Taxonomy and Multivariate Analysis System). Ver. 2. Department of Ecology and Evolution, State University of New York. Exeter Publ. Ltd., Setauket, New York, USA.

25. De Barro, P.J. and F. Driver, 1997. Use of RAPD PCR to distinguish the $\mathrm{B}$ biotype from other biotypes of Bemisia tabaci (Gennadius) (Hemiptera: Aleyrodidae). Aus. J. Entomol., 36: 149-152. http://www3.interscience.wiley.com/cgibin/fulltext/118676198/PDFSTART

26. Gawel, N.J. and A.C. Bartlett, 1993. Characterization of differences between whiteflies using RAPD-PCR. Insect Mol. Biol., 2: 33-38. DOI: 10.1111/j.1365-2583.1993.tb00123.X

27. Abdullahi, I., S. Winter, G.I. Atiri and G. Thottappilly, 2003. Molecular charcterisation of whitefly, Bemisia tabaci (Hemiptera: Aleyrodidae) populations infesting cassava. Bull. Entomol. Res., 93: 97-106. DOI: 10.1079/BER2003223

28. Maruthi, M.N., J. Colvin and S. Seal, 2001. Mating compatibility, life-history traits and RAPD PCR variation in Bemisia tabaci associated with the cassava mosaic disease pandemic in East Africa. Entomol. Exp. Appli., 99: 13-23. DOI: 10.1046/j.1570-7458.2001.00797.x

29. Brown, J.K., 2002. The molecular epidemiology of begomovirus. In: Plant Viruses as Molecular Pathogens. J.A. Khan and J. Dijkstra (Eds.). Haworth Press, New York, pp: 279-316. ISBN: 1560228946

30. Banks, G.K., J. Colvin, R.V.C. Reddy, M.N. Maruthi, V. Muniyappa, H.M. Venkatesh, M.K. Kumar, A.S. Padmaja, F.J. Beitia and S.E. Seal, 2001. First report of the Bemisia tabaci B biotype in India and an associated tomato leaf curl virus disease epidemic. Plant Dis., 85: 231. DOI: 10.1094/PDIS.2001.85.2.231C

31. Polston, J.E. and P.K. Anderson, 1997. The emergence of whitefly-transmitted geminiviruses in tomato in the Western Hemisphere. Plant Dis., 81: 1358-1369. DOI: 10.1094/PDIS.1997.81.12.1358

32. Rekha. A.R., M.N. Maruthi, V. Muniyappa and J. Colvin, 2005. Occurrence of three genotypic clusters of Bemisia tabaci and the rapid spread of the B biotype in south India. Entomol. Exp. Appli., 117: 221-233. DOI: 10.1111/j.1570-7458.2005.00352.x

33. Lisha, V.S., B. Antony, M.S. Palaniswami and T.J. Henneberry, 2003. Bemisia tabaci (Homoptera: Aleyrodidae) biotypes in India. J. Econ. Entomol., 96: 322-327. DOI: 10.1603/00220493(2003)096[0322:BTHABI]2.0.CO;2 